\title{
Jordan E-Government Challenges and Progresses
}

\author{
doi:10.3991/ijac.v3i1.1164 \\ Dr. Muhannad Al-Shboul ${ }^{1}$, Dr. Izzat Alsmadi ${ }^{2}$ \\ ${ }^{1}$ The University of Jordan, Amman, Jordan, ${ }^{2}$ Yarmouk University, Irbid, Jordan
}

\begin{abstract}
For several years, Jordan has been working in building and improving its e-government infra structure. As a result, there have been some improvements in the position of Jordan e-government relative to the worlds' egovernments (according to some reports). However, some metrics and statistics about the online users do not indicate that there is a large percent of Jordanian citizens who are using or utilizing e-government websites. This research tries to evaluate the progresses and weaknesses in those websites. It also focuses on the lack of local certificate authorities in Jordan as one of the major factors that is limiting the overall online business and activities in Jordan. There are few websites in Jordan that are certified (by international third parties). This forces those websites to outsource trust to third international parties. Digital certificates are one of the major required parts for building an infrastructure for the e-government in particular and the e-business in general.
\end{abstract}

Index Terms-E-commerce, government information systems, Digital certificates, Certification Authority, e-business, PKI, and digital signature.

\section{INTRODUCTION}

Jordan is considered one of the pioneer countries in the Middle East in the telecommunication and information technology sectors. It possesses a relatively rich infrastructure that contains fiber optics, coaxial, and wireless channels for all types of modern communications. Jordan also is considered one of the few small Middle Eastern countries that have the qualified human resources for all Information technology (IT) sectors.

However, the overall progress in this field is still relatively behind expectations. For years, Jordan has been working in building the infrastructure, and introducing the suitable laws required for the readiness of the egovernment. In this study, we will try to realistically evaluate the overall achievements and opportunities for the success of this initiative. The second part of the research will focus on Certificate Authority (CA) and digital certificates as an important missing factor for the success of the e-government and the existence and expansion of ebusiness in Jordan.

Digital identification is increasingly evolving in use and importance as a method to safely identify humans or entities especially through on-line business transactions. Through history, several techniques are used to uniquely identify individuals. Up to date, writing signatures are significant and required to verify that the person filling an application for example, is the same person he or she claims to be. Biometric signatures such as finger prints, iris patterns of the eyes, retina scans, DNA, voice prints, facial features, etc. are important and are able to uniquely identify an individual. However, none of those signatures can be conveniently implementing on-line to complete a transaction in a short time with a reasonable cost.
Public Key Infrastructure (PKI) is a set of technologies and security policies used to issue, revoke, and manage digital certificates and key pairs [1].

In digital certificates, users are identified by the information embedded on their machines, and verified by mutually trusted third party entities called Certification Authorities (CA) (such as Thawte or Verisign), that guarantees that the website operating is who it claims to be [2].

CA issues and manages digital certificates. They are third party trusted entities to authenticate sellers to buyers, banks to customers, email servers to email users, etc. In general, you are not supposed to expose any personal or financial information in any website that does not have a valid certification.

There are some requirements for any company or entity that wish to become a certificate authority who issues certificates to clients. As a hardware requirement, digital certificates are usually created by certificate servers such as Cisco IOS, Microsoft certificate server, EverLink, etc. CA's should make sure that their certificate database is secured from being accessed or hacked by invaders.

There are several forms of digital certificates. In this first type of certificates, software companies send their keys (public keys) to their customers. Customers will return back a certificate that combines the software company's public key with their private key (which includes specific information taken from their computers to include unique identifiers that distinguish a computer from all other computers). This information may include MAC addresses, IP address, CPU and hard drive unique identifiers, etc. The digital certificate will be encrypted so that its information will not be readable if retrieved by unauthenticated users. It can be understood only by those who issued it. Figure 1 shows a sample of a digital certificate retrieved from a computer.

In a second type, users can also gain self or individual certificates if they wish to uniquely identify them through online transactions. There are some companies who can provide such individual certificates for free.

The third type of digital certificates, which is our focus here, is those digital certificates that are gained by websites who wants to allow users to enter personal or financial information online. They want their users to trust them and feel secure entering their personal or financial information. Examples of such websites include: banks, hotels, e-businesses (such as Amazon, Ebay, etc.), and email servers (such as Yahoo and Gmail).

There are different models for CA's. In the traditional model or infrastructure for the Public Key Infrastructure (PKI), a company or entity will submit their information and request to a certificate authority. The CA will review the submitted information and decided whether to issue a certificate or not. The certificate will be issued for a speci- 


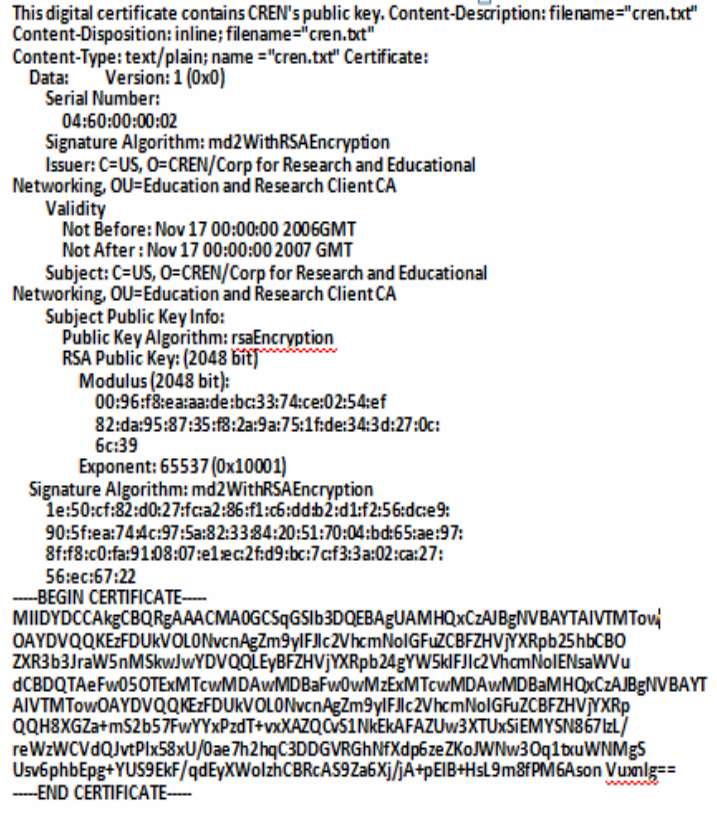

Figure 1. A digital certificate example.

fic limited time. The same process is repeated whenever the certificate is renewed. This type of certification is not dynamic or real time. This means that the CA does not check the validity of the CA upon requests. The entity will possess the certification for the specified amount.

In another model, the certificate are requested and authorized, or declined upon request. This process is expected to be more secure, but more complex than the earlier one. In different flavors of the models, the transaction content will, or will not be sent with the authorization request. As such, some entities will be authenticated in general, while others will be authenticated to do specific transactions.

Digital certificates are trusted identifications in electronic formats that bind a public encryption key to an identity to achieve public trust in that identity. They are a major factor in giving users confidence in websites and their legitimacy.

Some digital certificates can be transferred from one machine to another. Others generate the individual private key using some of the machine information such as the MAC address, computer name, etc. This means that those certificates can not be used on other machines - without being reinitialized by the CA or the company who issued it.

Typically, two things distinguish a certified website: the letter "s" after http, and the certificate header in the right side of the address bar (Figure 2 and 3). The "s" in "https" means that you are logging onto a Secure Socket Layer (SSL) site.

If you view the certificate from the web browser, it will display three main information: issued to, issued by and the validity period.

\section{Certificate Authorities IN Middle EAST}

Some companies such as Comtrust [3] offer digital certificates in United Arab Emirates (UAE). They provide PKI technologies and authorize digital certificates for ser-

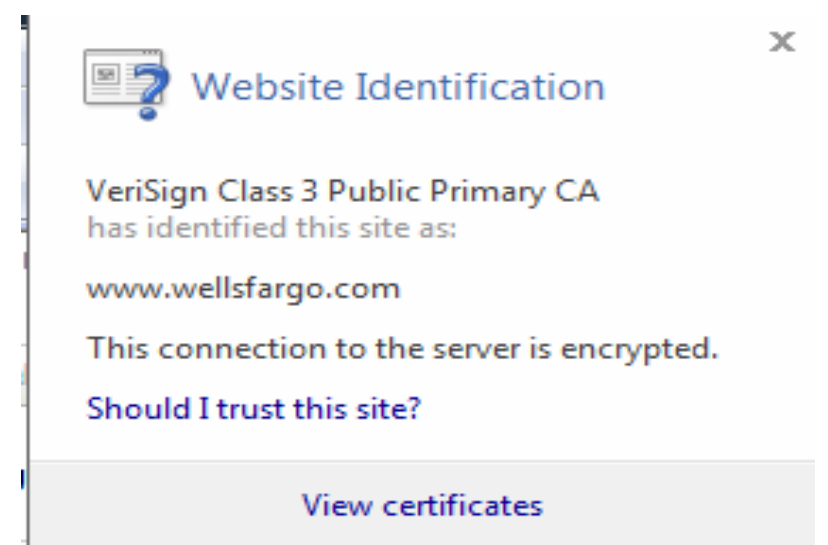

Figure 2. A typical certified website user interface.

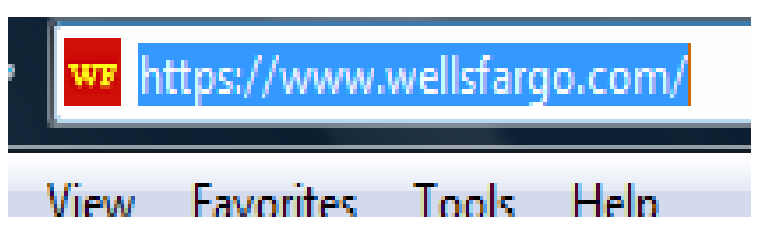

Figure 3. A URL address of a certified website.

vers, companies and individuals. Nevertheless, they still require individuals to come in person to verify their identity. In Egypt, digital certificates are issues through some companies such as: ITIDA (Root-CA, Trento Egypt and Gateway, LINKdotNET, etc... Egypt experienced research and proposals e-government services to allow citizens to process some papers on line. In Saudi Arabia, is in the progress of authorizing certificates, secure emails and several other e-government and e-business solutions. Some companies or agencies who are working toward this goal are: SAMA, Entrust partnership, Israel has several CA companies that issue certificates such as: ComSign, IUCC, StarCom, etc.

Jordan started early in studying the possibilities if implementing on-line security. In 2002, a joint effort by Middle East Communications Corporation (MEC) and WISekey Switzerland is initiated to allow MEC issuing digital certificates in Jordan [4]. It was expected to be in use by the year 2004 .

In 2003, Jordanian ESKADENIA Software Solutions worked in a project to be a local dealer for UAE Comtrust to market e-business services in Jordan [5]. However, neither one of those projects apparently reached a deliverable goal.

In an article published in June $14^{\text {th }} 2006$ in the Ministry of Information and Communications Technology (MoICT) [5], the document envisions a plan for an egovernment through a plan over the period of 2006-2009. Several laws and regulations were issued to regulate online services. The article concluded by the assessment for critical success factors and risks. Table1 shows the critical success factors and Table2 shows the risk elements.

Tables1 and 2 summarize some of the obstacles and barriers for implementing e-government including offering on-line identities, digital certificates, and several other on-line related services.

Ahmed and Hussein Al-Omari [7] similarly listed some of obstacles and challenges such as organizations, government and customers' readiness. 
TABLE I.

CRITICAL SUCCESS FACTORS.

\begin{tabular}{|c|c|}
\hline Critical Success Factor & Require \\
\hline Availability of resources (HR) & Commitment by Gov of Jordan \\
\hline $\begin{array}{l}\text { Availability of local skills to } \\
\text { implement and use e- } \\
\text { Government }\end{array}$ & $\begin{array}{l}\text { Develop courses locally } \\
\text { School/College/ University to re- } \\
\text { skill people }\end{array}$ \\
\hline $\begin{array}{l}\text { Availability of local skills to } \\
\text { implement and use e- } \\
\text { Government }\end{array}$ & $\begin{array}{l}\text { Incentives to e-Government stake- } \\
\text { holders to strengthen e-Gov related } \\
\text { skills }\end{array}$ \\
\hline $\begin{array}{l}\text { Availability of Laws and regu- } \\
\text { lations that support the imple- } \\
\text { mentation of e-Government }\end{array}$ & $\begin{array}{l}\text { Active coordination among con- } \\
\text { cerned agencies to develop and } \\
\text { enforce coherent and effective legal } \\
\text { framework }\end{array}$ \\
\hline $\begin{array}{l}\text { Cooperation and harmony } \\
\text { among government entities in } \\
\text { decision making for e- } \\
\text { Government initiatives }\end{array}$ & $\begin{array}{l}\text { Appoint and activate the National e- } \\
\text { Government Steering Committee } \\
\text { eGSC }\end{array}$ \\
\hline $\begin{array}{l}\text { Ability and willingness of gov- } \\
\text { ernment entities to document } \\
\text { and share their business re- } \\
\text { quirements, processes, services, } \\
\text { data and strategies }\end{array}$ & $\begin{array}{l}\text { Active coordination among gov- } \\
\text { ernment entities to document and } \\
\text { share information necessary for e- } \\
\text { Gov initiatives }\end{array}$ \\
\hline $\begin{array}{l}\text { Political commitment to ensure } \\
\text { "buy in” by gov entities across } \\
\text { government }\end{array}$ & $\begin{array}{l}\text { Appoint and activate the National e- } \\
\text { Government Steering Committee } \\
\text { eGSC }\end{array}$ \\
\hline Internet channel penetration & $\begin{array}{l}\text { Telecom sector development, } \\
\text { regulatory framework to promote } \\
\text { competition }\end{array}$ \\
\hline $\begin{array}{l}\text { Private sector capacity to par- } \\
\text { ticipate in / } \\
\text { support e-Gov }\end{array}$ & ICT sector development \\
\hline \multirow{4}{*}{$\begin{array}{l}\text { Sustainability of e-Gov imple- } \\
\text { mentation } \\
\text { despite political changes and } \\
\text { reshuffle of gov } \\
\text { officials }\end{array}$} & $\begin{array}{l}\text { Appoint and activate the National e- } \\
\text { Government Steering Committee } \\
\text { eGSC }\end{array}$ \\
\hline & $\begin{array}{l}\text { Passage of e-Gov regulations and } \\
\text { other actions to secure endorsement } \\
\text { at top levels of government }\end{array}$ \\
\hline & $\begin{array}{l}\text { Development of “champions” at key } \\
\text { ministries / entities; development of } \\
\text { administrative will for e-Gov initia- } \\
\text { tives }\end{array}$ \\
\hline & $\begin{array}{l}\text { Recognition of e-Government as a } \\
\text { priority in National Agenda }\end{array}$ \\
\hline
\end{tabular}

However, it is fair to say that some of those obstacles are not exclusively related to Jordan or any third world country. This field is quickly evolving in a way that presents a difficulty for public or government entities to keep up with. Governments are not expected to take the major role in such field. The governments will be responsible in making sure that there is an infrastructure for handling all related activities.

Laws and regulations should be established to control on line business and activities. The government should promote using digital certificates and on-line business through cooperation and acceptance. Internal or external investors should be invited and helped in building an infrastructure for establishing such environment. There is no much difference between this field and the wireless and cell phones communications. They both require large investment to build a reliable infrastructure. As a result, investments need to see a commitment from governments for cooperation. Using digital certificates can be a one important step to facilitate e-business. Jordan does not
TABLE II.

E-GOVERNMENT RISKS.

\begin{tabular}{|l|l|}
\hline \multicolumn{1}{|c|}{ Risk } & \multicolumn{1}{|c|}{ Mitigation / Contingency } \\
\hline $\begin{array}{l}\text { Cost of e-Government is } \\
\text { too high for the GOJ }\end{array}$ & $\begin{array}{l}\text { Realistic, well-sequenced phases } \\
\text { for e-Gov rollout }\end{array}$ \\
\cline { 2 - 2 } & $\begin{array}{l}\text { Develop pilot projects that can be scaled } \\
\text { later based on demand and biz CA'se }\end{array}$ \\
\cline { 2 - 2 } & $\begin{array}{l}\text { Encourage use of innovative commercial } \\
\text { arrangements (PPPs) attractive to private } \\
\text { sector for investment in e-Gov }\end{array}$ \\
\cline { 2 - 2 } & $\begin{array}{l}\text { Encourage strategic partnerships with } \\
\text { specialized international vendors to } \\
\text { invest in e-Government }\end{array}$ \\
\hline $\begin{array}{l}\text { Conflicting decisions } \\
\text { among government de- } \\
\text { partments }\end{array}$ & $\begin{array}{l}\text { Use of inter-agency working groups with } \\
\text { clear authority to supervise and enforce } \\
\text { e-Gov policies and standards }\end{array}$ \\
\hline $\begin{array}{l}\text { Resources within GOJ do } \\
\text { not have the skills to im- } \\
\text { plement e-Gov Strategy }\end{array}$ & $\begin{array}{l}\text { 1. Support to government entities for IT } \\
\text { training and other necessary Skills 2. } \\
\text { Recruit staff with relevant skills } \\
\text { 3. Incentives for gov entities to invest in } \\
\text { developing ICT expertise internally } \\
\text { 4. Outsourcing certain functions when } \\
\text { business CA'se supports it } \\
\text { 5. Create links with local universities to } \\
\text { give on-the-job-training to students } \\
\text { 6. Promote retention of skilled profes- } \\
\text { sionals in cooperation with other pro- } \\
\text { grams (e.g., Reach) }\end{array}$ \\
\hline Resistance to change \\
high
\end{tabular}

lack technical problems in the telecommunication and industry fields. On contrary, it is a pioneer country in Middle East in those fields. It also provides several other countries in the region with the personnel support and experience.

\section{JORDAN E-GOVERNMENT; CHALLENGES AND PROGRESSES.}

Currently, Jordan offers several e-services to citizens. They can inquire about several related information such as [8]: Amman Municipality (vehicles ticketing and complaints), driver and vehicle licenses department (vehicle license expiration date), Jordan custom (Inquiry about vehicle custom, guarantee orders, etc), Amman (Water Bills), Income and sales tax department (income balance for individuals), housing and urban development corporation.

However, user can inquire - and not pay for example for those services. There isn't any usage of digital certificates ( not even the e-government websites themselves). According to the income and sales tax department website (http://www.incometax.gov.jo/IncomeTax/Home/Login.as $\mathrm{px}$ ), users can inquire and pay their taxes on line. The website states that it is certified, however, it doesn't seem to be using digital certificates. The website does not allow users to create their user name and password which indicate that they may need to register in person first. 
Doing a survey for Jordan banks, very few banks, such as the Arab bank, Arab Jordan investment bank, the housing bank, etc. use digital certificates and secure on line transactions - verified by VeriSign CA, a widely known international certificate authority-, others do not have on line access at all, and the third category offers on line services without secure transactions which may cause customers' information to be compromised. As an on-line user, before entering your personal or financial information on-line, you should check the certificate, to verify the identity of the website you are entering your information into. Without such information, you could by giving your information to unknown individuals that may reuse it without prior knowledge. Similar to e-businesses, banks are the second major category that will benefit from digital certificates.

Figure 4 shows the certificate market share for CA's in Jordan [9]. The international certificate authority; VeriSign, is taking the majority of the market share. Table 3 shows the number of certified websites in selected countries as of 2006 [9]. Jordan has only 26 websites (largely banks), which is relatively a very small number of websites if it will be compared to the readiness of Jordan (in resources and infrastructure). In most studies to evaluate e-governments worldwide [10, 11, 12, 13, 14, 15], Jordan scores relatively low in citizen's participation. Citizens will be encouraged to visit e-government websites if they can provide them alternative services to check their taxes and pay them, check their electric, water, and phone bills and pay them, or see the status of any info or service they are requesting from a governmental entity. All those services may not be possible without digital certificates.

As described earlier, there have been several unsuccessful trials by local companies to establish certificate authorities in Jordan. They maybe were having problems getting the right authentication and trust from government and private sectors. As an alternative, Jordan government, represented by any entity or ministry such as Jordan Ministry of Information and Communications Technology (MOICT) can be a certificate authority that will authenticate certificates for all those who are requesting to have them.

\section{CONCLUSION AND FUTURE WORK}

Jordan took several steps toward the establishment of an e-government. Individuals can save time and effort by accessing their information on line and without a need to personally visit government departments. However, the roadmap for e-business faces a lot of challenges yet to be solved.

In this paper, we suggested that, in order to boost the roadmap for using digital certificates and on-line transactions, the government should promote the private sector to compete and take the lead in building the required infrastructure rather than building it itself. This can ensure a continuous fast growing of this industry to handle an evolving technology. As an alternative, it may act as the first authority to issue certificates. Such an alternative maybe necessary in Middle Eastern countries.

Customers need to learn how to communicate on line. They need to learn how to shop, sincerely post items on line, committed to pay and ship on time. Businesses also need to be opened toward some necessary ethical e-

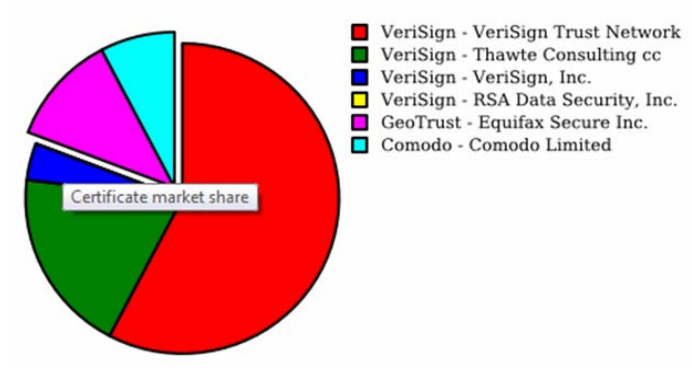

Figure 4. Certificate market share for CA's in Jordan [9].

TABLE III.

NUMBER OF CERTIFIED WEBSITES IN JORDAN AND SOME SELECTED COUNTRIES [9].

\begin{tabular}{|c|c|c|c|}
\hline Country & $\begin{array}{c}\text { No. of servers } \\
\text { certified }\end{array}$ & Country & $\begin{array}{c}\text { No. of servers } \\
\text { certified }\end{array}$ \\
\hline USA & 250558 & Lebanon & 38 \\
\hline UK & 31870 & Iran & 26 \\
\hline Turkey & 1528 & Jordan & 26 \\
\hline Israel & 1221 & Morocco & 24 \\
\hline UAE & 222 & & \\
\hline KSA & 90 & Qatar & 17 \\
\hline Kuwait & 83 & Tunisia & 16 \\
\hline Egypt & 46 & Oman & 8 \\
\hline Bahrain & 44 & Algeria & 4 \\
\hline
\end{tabular}

business manners such as giving their buyers certain period for returning the items or changing them.

Jordan internet infrastructure is strong and capable of handling the construction of a trusted network. The private sector should take the lead in PKI and digital identity infrastructure. Once such infrastructure is established, many of those related and dependent industries can exist and provide an important economical input to the national revenue.

In future, we will follow up with two research projects. We will create surveys to evaluate strengths and weaknesses in e-government implementation in Jordan. We will try to distribute the survey among those who can provide the right useful information for the purpose of the study.

The second track will use web metrics to evaluate the traffic and usage of e-government websites in Jordan. This stage is expected to give us a better image about the actual usage of those websites. It may indicate weaknesses or strengths in particular websites. In order to do that, we may need the assistant and the cooperation of egovernment websites administrators to get websites log or to add scripts to monitor those websites.

\section{REFERENCES}

[1] Secure computing corporation. Digital certificates. http://www.securecomputing.com/gateway/digital_certificates.cfm , 2008.

[2] Conjecture corporation. What are digital certificates. http://www.wisegeek.com/what-are-digital-certificates.htm. 2008.

[3] Comtrust. http://www.comtrust.co.ae-/docs/contactus.htm. 2008.

[4] WISekey. http://www.wisekey.com/-press/jordan32002.htm. 2002. 2008.

[5] Jordan e-government program, e-Government strategy. http://www.moict.gov.jo/moict/e gov strategy/e-Government $\% 20$ Strategy.pdf. 2006. 2008. 


\section{JoRDAN E-GovernMENT CHALLENGES AND PROGRESSES}

[6] Comtrust ties up Jordanian company ESKADENIA. AME Info. $<$ http://www.ameinfo.com/26458.html >. 2003. 2008.

[7] Ahmed Al-Omari and Hussein Al-Omari. E-Government Readiness Assessment Model. J. Computer Sci., 2 (11): Pages: 841845, 2006. http://www.scipub.org/fulltext/jcs/jcs211841-845.pdf.

[8] Zain - Jordan Mobile Telephone Services. http://www.jo.zain.com/English/Business/BusinessServices/Pages/ E-Government.aspx, 2008.

[9] Netcraft, Certificate services. http://news.netcraft.com/SSLSurvey/CMatch/certs. 2006. 2008.

[10] Holzer, Mark, and Seang-Tae Kim. DIGITAL GOVERNANCE IN MUNICIPALITIES WORLDWIDE, An Assessment of Municipal Web Sites Throughout the World. The E-Governance Institute/ National Center for Public Productivity Rutgers, the State University of New Jersey, Campus at Newark. 2003.

[11] Holzer, Maroc, and Aroon Manoharan. Global Trends in Municipal E-Government: An Online Assessment of Worldwide Municipal Web Portals.

[12] Holzer, Mark, and Seang-Tae Kim. DIGITAL GOVERNANCE IN MUNICIPALITIES WORLDWIDE (2007), A Longitudinal Assessment of Municipal Web Sites Throughout the World. The E-Governance Institute/ National Center for Public Productivity
Rutgers, the State University of New Jersey, Campus at Newark. 2007.

[13] West, Darrel. Global e-government. http://www.insidepolitics.org/ egovtdata.html. 2005.

[14] West, Darrel. Global e-government. http://www.insidepolitics.org/ egovtdata.html. 2006.

[15] West, Darrel. Global e-government. http://www.insidepolitics.org legovtdata.html. 2007.

\section{AUTHORS}

Dr. Izzat Alsmadi is with the Department of Computer Information Systems, Yarmouk University, Irbid, CO 21163 Jordan (e-mail: ialsmadi@yu.edu.jo).

Dr. Muhannad Al-Shboul is a member of the Researchers' Association and with the Computer Center, The University of Jordan, Amman, CO 11942 Jordan (e-mail: malshboul@ju.edu.jo).

This article was modified from a presentation at the International Conference on Interactive Mobile and Computer Aided Learning (IMCL2009) in Amman, Jordan, April 2009. Submitted, January, 13, 2010. Published as resubmitted by the authors on February, 2nd, 2010. 